Abstracta Iranica Abstracta Iranica

Revue bibliographique pour le domaine irano-aryen

Volume 24 | 2003

Comptes rendus des publications de 2001

\title{
« Freeing Astronomy from Philosophy. An Aspect of Islamic Influence on Science ». Osiris, 16, (2001), pp. 49-71.
}

\section{Živa Vesel}

\section{(2) OpenEdition}

Journals

Édition électronique

URL : http://journals.openedition.org/abstractairanica/34586

DOI : 10.4000/abstractairanica.34586

ISSN : 1961-960X

Éditeur :

CNRS (UMR 7528 Mondes iraniens et indiens), Éditions de l'IFRI

\section{Édition imprimée}

Date de publication : 15 mai 2003

ISSN : 0240-8910

Référence électronique

Živa Vesel, « «Freeing Astronomy from Philosophy. An Aspect of Islamic Influence on Science ». Osiris, 16, (2001), pp. 49-71. », Abstracta Iranica [En ligne], Volume 24 | 2003, document 192, mis en ligne le 05 janvier 2010, consulté le 25 septembre 2020. URL : http://journals.openedition.org/abstractairanica/ 34586 ; DOI : https://doi.org/10.4000/abstractairanica.34586

Ce document a été généré automatiquement le 25 septembre 2020.

Tous droits réservés 
« Freeing Astronomy from Philosophy. An Aspect of Islamic Influence on Science ». Osiris, 16, (2001), pp. 49-71.

Živa Vesel

1 À l'aide d'exemples, discussion nourrie sur des rapports qu'entretiennent les sciences islamiques avec la philosophie et les matières scientifiques, sujet complexe qui évite ici l'approche caricaturale qui lui est habituellement réservée. Selon l'auteur, le contexte religieux pouvait être bénéfique au développement de la science, comme par exemple dans le fait de libérer l'astronomie de ses liens philosophiques. Les attaques des milieux religieux étaient à même d'entraîner une attitude plus critique de la part des savants envers leur propre domaine.

INDEX

Thèmes : 10. Histoire des Sciences et des Techniques

\section{AUTEURS}

ŽIVA VESEL

CNRS - Paris 